\title{
Different Modalities of Flap Coverage of Achilles Tendon Region Defects: Functional and Aesthetic Outcomes
}

\author{
TAHER M. ELGHAZALY, M.B.B.Ch.; TAREK F. KESHK, M.D.; MOHARAM A. MOHAMED, M.D. and \\ AHMED A. TAALAB, M.D. \\ The Departments of Plastic \& Reconstructive Surgery, Shebin El-Kom Teaching Hospital and Faculty of Medicine and \\ General Surgery, Faculty of Medicine, Menoufia University
}

\begin{abstract}
Background: In the decision-making process toward covering various Achilles' tendon region, knowledge about patient related outcomes after surgery and rehabilitation is important. Therefore, we aimed to present an overview of outcomes and select the most appropriate flaps used for covering soft tissue defects over Achilles' tendon region.

Aim of Study: Study aimed to analyse and determine the suitable reconstructive surgical options for Achilles' tendon coverage and to evaluate the clinical, functional and aesthetic outcomes.

Patients and Methods: Between September 2017 and December 2019, 25 patients with skin loss over Achilles' tendon region were admitted to Menoufia University Hospital and Shebin-Elkom Teaching Hospital. The soft tissue defects ranged from $3 \times 2$ to $16 \times 12 \mathrm{~cm}$. Six types of flaps were used for the coverage of concomitant skin defects.

Results: There was no complete flap loss and all flaps survived. Lateral supra malleolar flap $(28 \%)$ was used in seven patients, distally based peroneus brevis muscle flap $(16 \%)$ in four patients, posterior tibial artery perforator flap $(24 \%)$ in six patients, peroneal artery perforator flap (4\%) in one patient, reversed sural artery flap (24\%) in six patients, and free latissimus dorsi musculocutaneous flap (4\%) in one patient. Two patients were subjected to debridement and covered with split thickness skin graft (STSG). One patient suffered from chronic ulcer formation which was covered with lateral supra malleolar artery flap. The algorithm of onestage reconstruction was established, according to the defect size of skin.

Conclusion: Perforator flaps, lateral supra malleolar artery flap, and the distally based peroneus brevis muscle flap were a suitable option for coverage of small to intermediate sized defects; reversed sural artery flap is best for coverage of moderate to large size defects and free flaps are the best choices for complex wide reconstructions.
\end{abstract}

Key Words: Achilles' tendon-Coverage - Soft tissue defects - Flaps.

Correspondence to: Dr. Taher M. Elghazaly, E-Mail: tahermohammedelghazally@gmail.com

\section{Introduction}

THE Achilles tendon (calcaneal tendon) is the largest and strongest tendon in the human body. It plays a vital role in walking, running, or jumping as it pulls on the heel upon flexion of the calf muscles $[\mathbf{1 , 2}]$. Due to its anatomic particularities, reconstruction and resurfacing of post-traumatic soft tissue defects of Achilles tendon region is a challenging task to plastic surgeons [3]

A great number of papers have been published, focusing on skin coverage of lower limb skin defects to prevent further infection and delayed amputation and to provide the best possible functional outcome. However, an ideal resurfacing should be stable, thin enough to allow footwear, obtain an anatomical contour and able to with stand shoe friction and providing a gliding surface for the underlying tendon [4]. The vast array of reconstructive methods should be used judiciously, considering the defect's characteristics and the functional and aesthetic requirements. Numerous procedures have been extensively described in literature for resurfacing Achilles' tendon soft tissue defects [3]. However, deciding which suitable specific flap with less morbidity according to each reconstructive situation is challenging.

Therefore, the main objective of our study is to analyse and determine the suitable reconstructive surgical options for Achilles' tendon coverage. We also aimed to evaluate the clinical outcomes of variable reconstructive options and assess association of complications with age, gender, flap size and arc of rotation.

\section{Patients and Methods}

This prospective study was carried out at Menoufia University Hospitals and Shebin El-Koum 
Teaching Hospital from September 2017 to December 2019. The study included 25 patients (19 males and 6 females) with soft tissue defects over Achilles' tendon region resulting mainly from trauma, and the patients' age ranged from 12 to 45 years. The etiologies of the defect were as follows: Posttraumatic in 17 cases $(68 \%)$, chronic non-healing ulcers in six cases (24\%), post oncologic excision in one case $(4 \%)$ and gunshot injury in one case $(4 \%)$ (Table 1). Post traumatic patients who required a vascularized tissue were included in this study. Patients who were treated with advanced medication, skin graft and patients with associated tendon injury or peripheral vascular disease were excluded.

All included patients underwent the standard preoperative preparation for surgery including laboratory and radiological investigations. General and local examinations were done including assessment of defect size, extent of injury, vascularity of the affected limb using color duplex, exposure of other structures other than the Achilles tendon and the integrity of surrounding skin. Also, preoperative and postoperative photographs were taken and documented. Patients also received preoperative prophylactic antibiotics. Ethical approval was obtained from the University and Hospital Institutional Review Boards, and an informed written consent was obtained from all patients.

On hospital admission, all patients received repeated debridement followed by daily dressing change on the soft tissue defect area. The defects varied in size between $3 \mathrm{~cm} \mathrm{x} 2 \mathrm{~cm}$ and $16 \mathrm{~cm} \mathrm{x}$ $12 \mathrm{~cm}$. Defect sizes were classified into small to medium size defects (less than $8 \mathrm{~cm} \times 6 \mathrm{~cm}$ ); medium to large size defects (up to $15 \times 7 \mathrm{~cm}$ ); and large wide defects (greater than $15 \mathrm{~cm}$ ).

\section{A- Operative technique:}

Under general or spinal anesthesia, all patients were placed in supine, prone or lateral position according to extension of wound and the flap used for coverage. A hand-held Doppler was used to detect the perforators and locate the pedicle position. The skin flap was outlined according to the defect of the recipient site. All surgical procedures were performed using a magnification loupe $(2.5 \mathrm{X}$ to $4.5 \mathrm{X}$ ) and under ischemia provided by a pneumatic thigh tourniquet inflated to $350 \mathrm{mmHg}$.

Flaps were outlined according to reconstructed soft tissue defects depending on the anatomy of the soft tissue injury and the location of the defect after a healthy wound is achieved by one or multiple debridement sessions. All patients were closely followed-up at an outpatient clinic until the transferred flap had successfully stabilized and survived.

The choice of flap was determined by available uninjured tissue on the donor site, and by the size and location of the defect. According to the defect size after excisional debridement, the posterior tibial perforator artery flap was performed in six patients (Fig. 1), the peroneal artery perforator flap in one patient, the lateral supra malleolar artery flap in seven patients (Fig. 2), the reverse sural artery flap in six patients, the peroneus brevis muscle flap in four patients (Fig. 3), and the latissimus dorsi musculocutaneous free flap in one patient (Fig. 4). The procedures were performed according to those described in the literature [510]. In the Latissimus dorsi free musculocutaneous flap, thoracodorsal vessels were end to end anastomosed to posterior tibial vessels after checking perfusion of the flap and split thickness graft was taken to cover the muscle part of the flap. Donor site of the used flaps were closed either primary or by applying split thickness graft. Flaps were loosely sutured. A bulky light-pressure dressing with a splint or external fixator were used to protect the wound and immobilize ankle.

Based on our clinical experience and the data available in the current literature, we suggested the following algorithm to orientate in the softtissue reconstruction of the Achilles region taking into consideration the size of defect and the tissues involved (Fig. 5).

\section{B-Postoperative care:}

Soft bandage was used to cover the flap site and an area was left exposed in order to check flap viability. Also, the operated limb was elevated for at least a week to facilitate venous drainage, reduce edema and pain in all patients. The flap was monitored regularly for vascular insufficiency and the first dressing was opened on the second postoperative day. All patients received STSG were uncovered on the fifth postoperative day. Broad-spectrum antibiotics (amoxicillin clavulanic acid and metronidazole) were administered for seven days postoperatively. Residual sequelae, pain, weakness and complications, and the patients' ability to return to their sporting and living activities were documented.

\section{C- Evaluation methods:}

Flap monitoring started six hours postoperatively, then every 12 hours for the first 48 hours, and then once every day by evaluating its temperature, color, capillary refilling, bleeding from pricking points and texture of the flap. Alternatively, 
the free flap was monitored every hour for the first 48 hours and then every six hours on the third day and then every 12 hours for the rest of the week. Donor site was also monitored for any problems such as loss of graft, paresthesia, hypertrophic scar or keloid formation. All patients were scheduled for follow-up one week after discharge and then at two weeks for stitch removal and fortnightly for at least three months.

\section{D- Statistical analysis:}

Data entry, processing and statistical analysis were entered and analyzed using SPSS software package (version 25.0, SPSS Inc, Chicago, Illinois, USA). Quantitative variables were calculated in terms of mean \pm SD and qualitative variables were calculated as frequencies and percentages. All analysis results with $p<0.05$ or $95 \%$ confidence level were considered statistically significant.

\section{Case Series:}

Case 1:

A female patient (34 years old) presented with pigmented round elevated mass over medial malle-
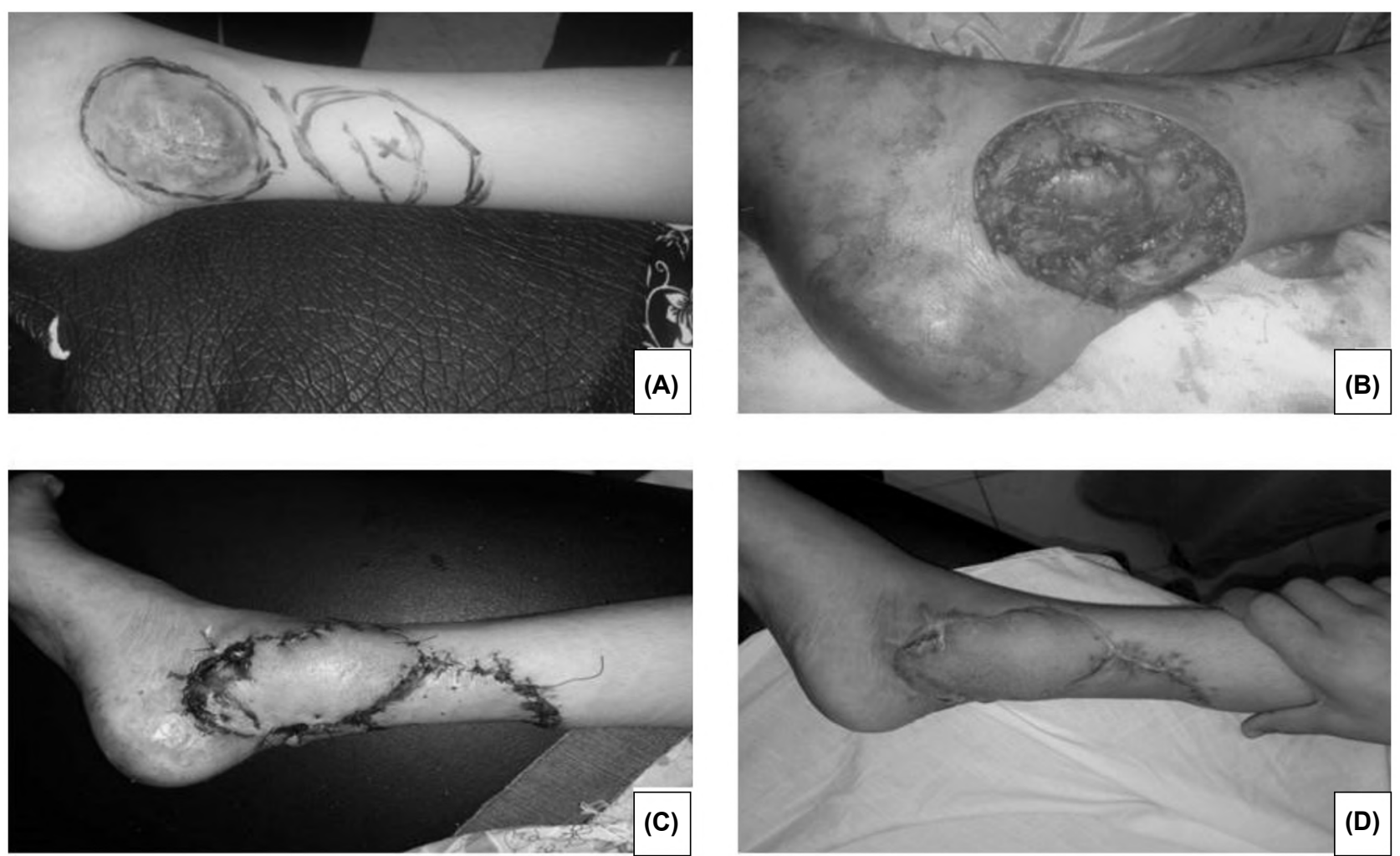

Fig. (1): (A) Preoperative marking of posterior tibial artery perforator flap. (B) Excision of the tumor and exposure of the olus of right leg nearly about $4 \mathrm{~cm} \times 4 \mathrm{~cm}$ suspected to be melanoma. The tumor was excised totally with a safety margin and sent for biopsy. Achilles' tendon was exposed after excision of the tumor with the medial malleolus. The raw area was about $5 \mathrm{~cm} \times 5 \mathrm{~cm}$. Posterior tibial perforator artery flap was raised, then rotated 110 degree to cover the raw area. Dimensions of the flap were $7 \mathrm{~cm}$ length $\mathrm{x} 6 \mathrm{~cm}$ width and the donor site was covered with a split-thickness skin graft (Fig. 1).

\section{Case 2:}

A male patient (29 years old), presented with degloving injury and skin and soft tissue loss over Achilles' region, dorsum of foot, and medial malleolus of right leg with open fracture in the distal third of the tibia due to post-traumatic road traffic accident. The fracture was fixed using external fixator immediately, then soft tissue resurfacing with internal fixation was performed six days later. After debridement the raw area was covered with free latissimus dorsi musculocutaneous flap. Split thickness skin grafts were used for coverage of the exposed muscle with no problems and the donor site was primarily closed (Fig. 4).

\footnotetext{
Achilles tendon with medial malleolus. (C) Postoperative after 5days. (D) Postoperative after two months.
} 

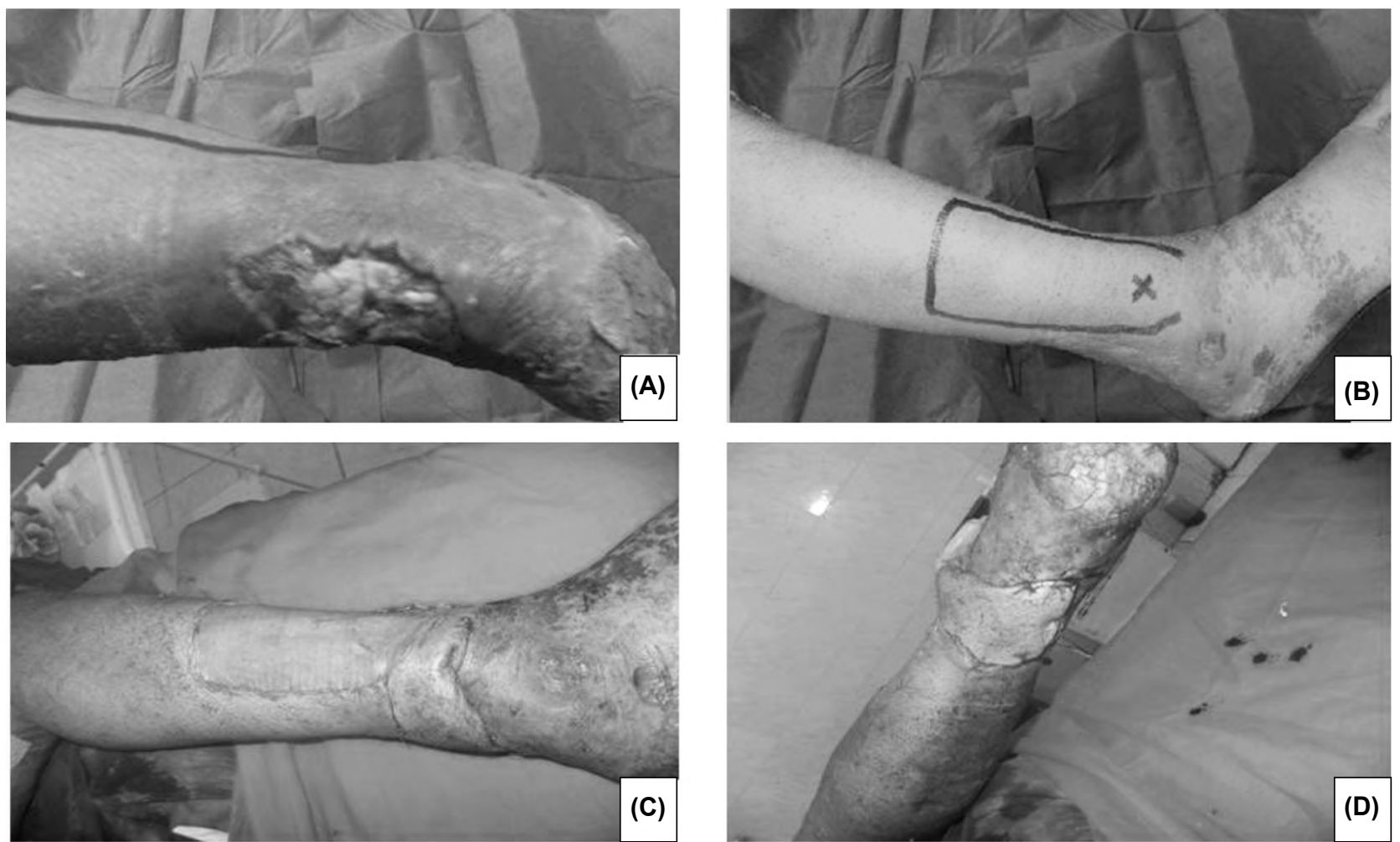

Fig. (2): (A) Chronic non healing diabetic ulcer over Achilles tendon of right leg. (B) Preoperative marking of lateral supra malleolar artery flap. (C,D) Postoperative after 5 days.
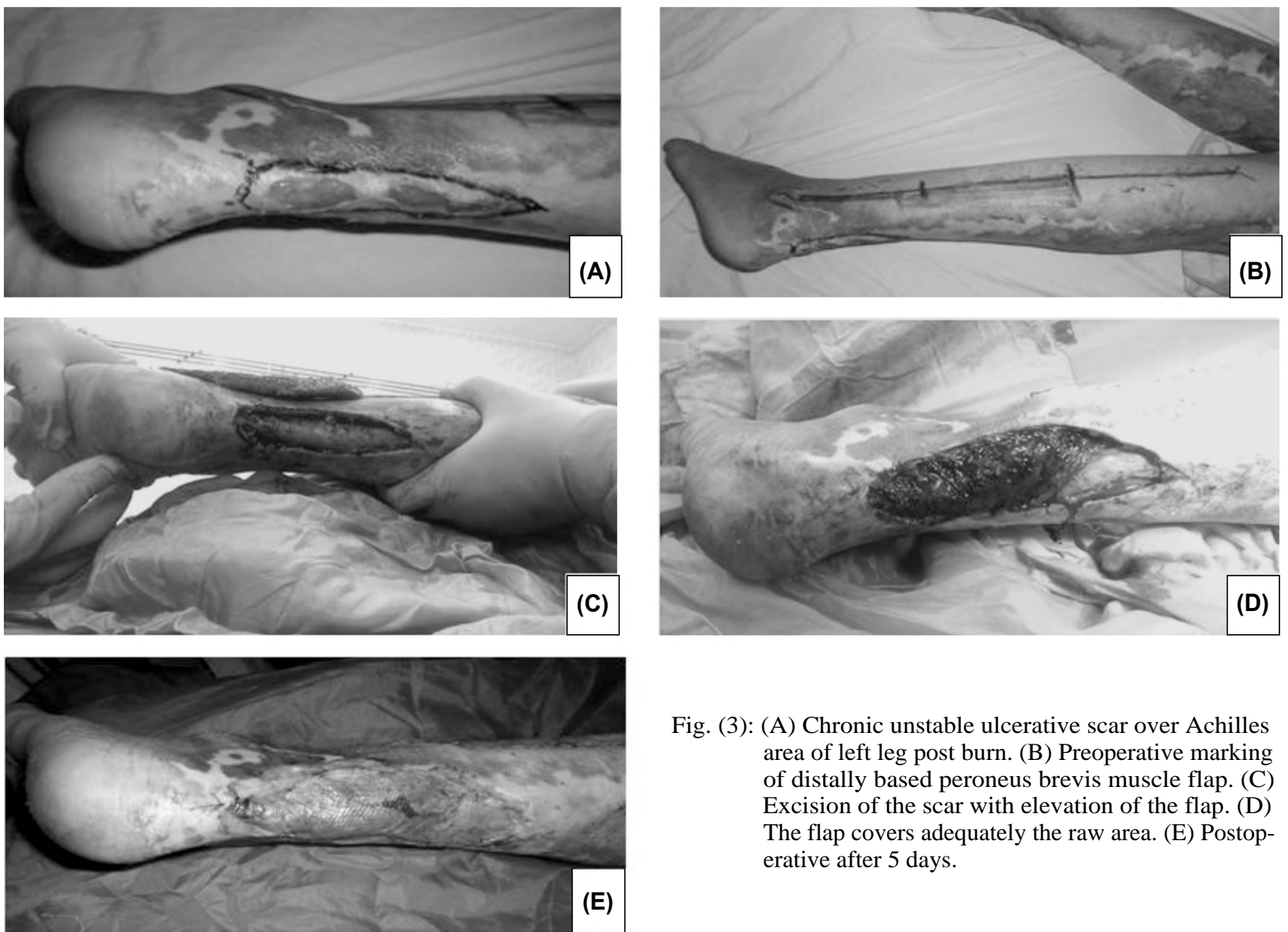

Fig. (3): (A) Chronic unstable ulcerative scar over Achilles area of left leg post burn. (B) Preoperative marking of distally based peroneus brevis muscle flap. (C) Excision of the scar with elevation of the flap. (D) The flap covers adequately the raw area. (E) Postoperative after 5 days. 

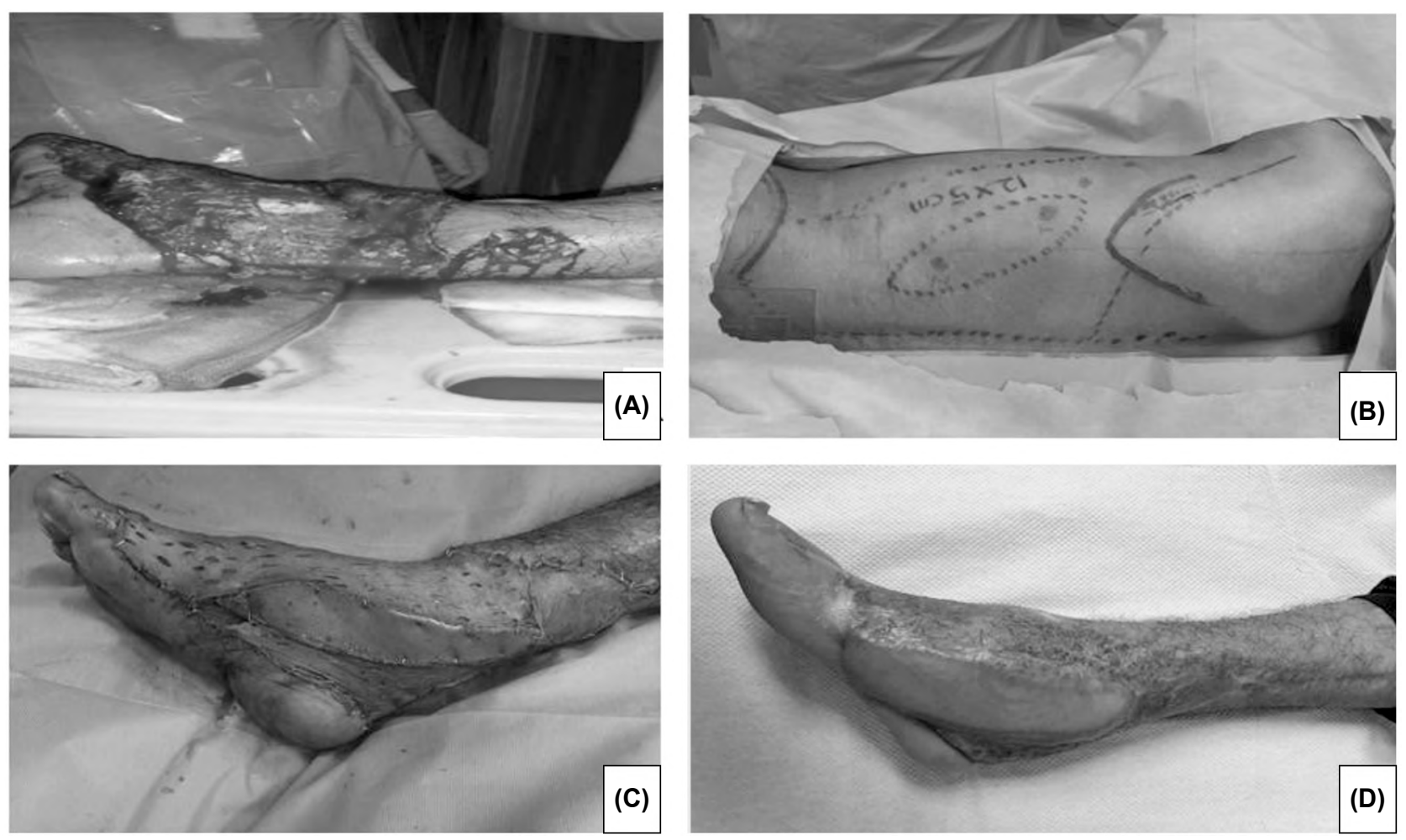

Fig. (4): (A) Degloving injury with loss skin and soft tissue over Achilles' area, dorsum of foot, and medial malleolus of right leg. (B) Preoperative marking of latissimus dorsi musculocutaneous flap. (C) The raw area was covered adequately by free latissimus dorsi musculocutaneous flap and Split thickness grafts were taken for coverage muscle part of the flap with no problems. (D) Postoperative after 2 months.

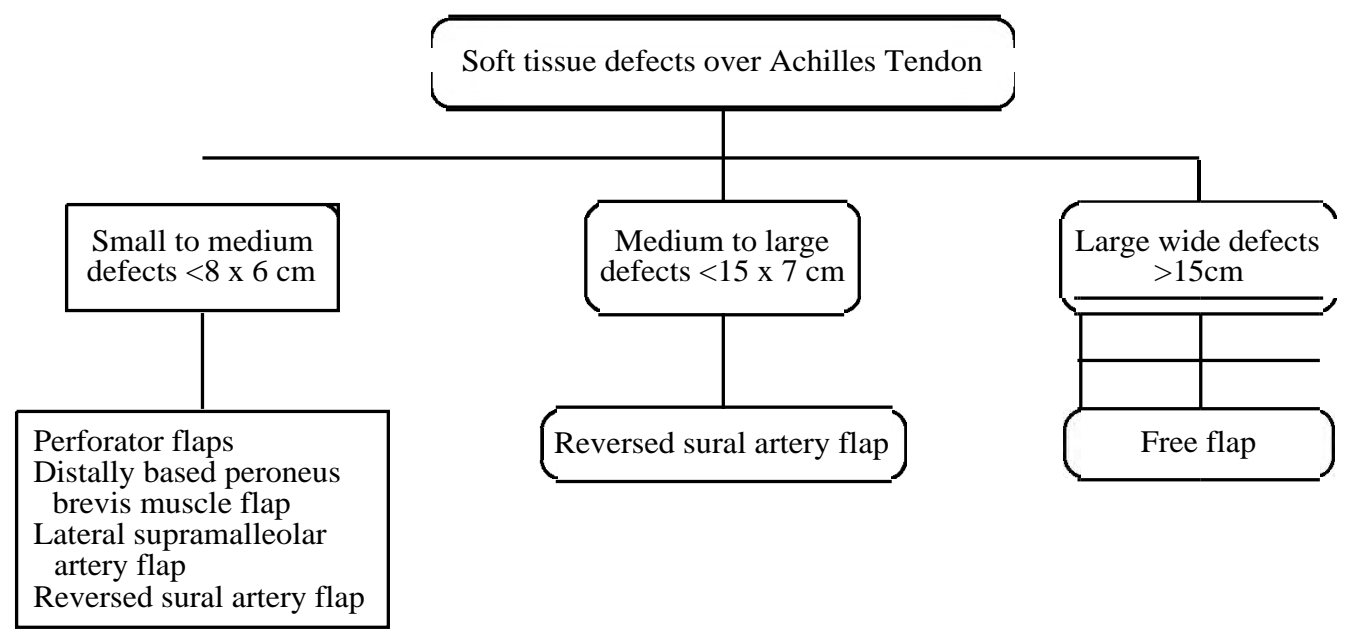

Fig. (5): The concluded coverage protocol according to our study.

\section{Results}

In our study, seven lateral supra malleolar flaps (28\%), four distally based peroneus brevis flaps (16\%), six posterior tibial artery perforator flaps $(24 \%)$, one peroneal artery perforator flap (4\%), six reversed sural artery flaps $(24 \%)$ and one free latissimus dorsi musculocutaneous flap (4\%) were successfully performed (Table 2 ).
Fifteen patients were covered immediately in the first three days after exposure of Achilles tendon and ten patients were postponed from a week to a month following debridement and repeated dressings to control infection and prepare bed for coverage.

All flaps survived. For the flap contours, 19 cases were satisfied in terms of aesthetic and 
functional outcomes and required no secondary thinning. Seven cases had a bulky flap, which caused difficulty in shoe wearing and received a secondary thinning surgery. Complications were recorded in six flaps (24\%). Marginal necrosis of the distal ends was noted in two flaps in the lateral supra malleolar artery flap patients; one flap was managed by split thickness skin graft and the other healed spontaneously. Similarly, the same complications were noted in two reversed sural artery flaps, where one flap received a skin graft and the other flap healed by secondary intention. On the other hand, ulceration and loss of the distal $3 \mathrm{~cm}$ of the graft occurred in the peroneus brevis muscle flap and was later revised by lateral supra malleolar artery flap.
Table (1): Demographic characteristics of patients included in the study.

\begin{tabular}{lll}
\hline Gender & Male & $19(76 \%)$ \\
& Female & $6(24 \%)$ \\
Age & $<20$ & $2(8 \%)$ \\
& $20-<30$ & $5(20 \%)$ \\
& $30-<40$ & $10(40 \%)$ \\
& $\geq 40$ & $8(32 \%)$ \\
Co-morbidities & Diabetic & $3(12 \%)$ \\
& Not diabetic & $22(88 \%)$ \\
& Smoker & $7(28 \%)$ \\
Cause of defect & Not smoker & $18(72 \%)$ \\
& Road traffic accident & $17(68 \%)$ \\
& Chronic non-healing ulcer & $6(24 \%)$ \\
& Tumour & $1(4 \%)$ \\
& Gun shot & $1(4 \%)$ \\
\hline
\end{tabular}

Table (2): Types of the flaps included in the study.

\begin{tabular}{lllllllll}
\hline \multirow{2}{*}{ Flap used } & \multicolumn{2}{c}{$\begin{array}{c}\text { Total } \\
\text { number }\end{array}$} & \multicolumn{2}{c}{$\begin{array}{c}\text { Good } \\
\text { results }\end{array}$} & & \multicolumn{2}{c}{ Complications } \\
\cline { 2 - 9 } & No. & $\%$ & No. & $\%$ & No. & $\%$ & Type \\
\hline Lateral supra malleolar artery flap & 7 & 28 & 5 & 72 & 2 & 28 & Marginal necrosis of distal ends of the flap \\
Peroneal artery perforator flap & 1 & 4 & 1 & 100 & 0 & 0 & None \\
Distally based peroneus brevis muscle flap & 4 & 16 & 3 & 75 & 1 & 25 & Loss of distal $3 \mathrm{~cm}$ of the graft \\
Posterior tibial perforator artery flap & 6 & 24 & 5 & 83 & 1 & 17 & $\begin{array}{c}\text { Partial superficial necrosis of distal end of } \\
\text { the flap }\end{array}$ \\
Reversed sural artery flap & & & & & & & Marginal necrosis of distal ends of the flap \\
Latissimus dorsi free flap & 6 & 24 & 4 & 67 & 2 & 33 & None \\
\hline
\end{tabular}

\section{Discussion}

Reconstruction of soft tissue defects in Achilles' tendon region presents a challenging problem for the plastic surgeon. A wide spectrum of local, regional, distant and free micro-vascular flaps has been described for covering these defects. There is no single reconstructive available option that is suitable for a specific defect size [3]. However, the main aim is to restore or preserve the Achilles tendon function and the coverage should be versatile and respond properly to the mechanical stress experienced in this region [11]. The heel skin directly covers the Achilles tendon, hence, defects in this region cannot be reconstructed with a skin graft. Therefore, a flap is necessary for providing effective coverage and in avoiding friction from shoes.

However, according to literature, muscle flaps and myocutaneous flaps are definitely not the best choice to cover Achilles' tendon because of the bulky and prone to adhesion with the underlying tendon. In addition, reverse sural flaps offer a good alternative for resurfacing soft tissue defects over the Achilles tendon region [12].

On the other hand, propeller flaps emerged as a very useful option in the reconstructive toolbox and gained increasing acceptance over the past decades [13]. The propeller concept increased the number of potential donor sites particularly in the Achilles region, where conventional pedicled flaps are not amenable. This might be because they do not have enough arc of rotation. Propeller flaps provide like with like option and offer a very low morbidity at the donor site [14,15]

This study was conducted at Menoufia University Hospitals and Shebin El-Koum Teaching Hospital between September 2017 to December 2019. It included 25 patients (19 males and 6 females) with variable soft tissue defects over Achilles' tendon region. The patients' age ranged from 12 to 45 years. The defects size ranged from $3 \times 2 \mathrm{~cm}$ to $16 \mathrm{x} 12 \mathrm{~cm}$ (Mean=6.5 $\pm 3,4.5 \pm 2.5$ for length and width respectively). Patients were either covered 
immediately in the first three days or were postponed from a week to a month. The exact timing was often difficult to decide, but it is largely accepted that once the wound is clinically and microbiologically clean, soft-tissue reconstruction should be performed [3]

Compared with those from the thigh and trunk, the flaps taken from the leg were invariably thinner, including the sural flap. In our experience, the choice of flap was mainly based on the defect size of the wound. Also, the surrounding soft tissue condition is a deciding factor as to which flap was more suitable for the transfer [16].

We performed the distally based peroneus brevis muscle flap in four patients with medium size defect. Three cases showed complete flap survival and coverage of the defect with no donor site morbidity. While, one patient expressed marginal flap loss of about distal $3 \mathrm{~cm}$, which was later revised with a lateral supra malleolar artery flap.

Our findings were similar to Sahu, et al., [17] He performed distally based peroneus brevis muscle flap in 25 cases over a period of 4 years to resurface soft tissue defects around the ankle. He also reported that out of 10 cases have defects in the Achilles area, six cases showed satisfactory results while, in four cases there were complications in the form of distal flap necrosis and graft loss.

In our study, reversed sural artery flap was used in six patients to cover raw area in the Achilles region. The defects varied in size from small to large defects. One patient was covered by reversed sural artery flap with skin island. Four patients showed satisfactory results while, two patients experienced distal flap necrosis. Debridement and later coverage with split thickness skin graft was done to one case and showed adequate result while, the other cases with minimal flap loss healed successfully by secondary intention. LAL S [18] reported similar results in which 12 cases of reversed sural artery of flap were done over a period of two years to cover intermediate to large size soft tissue defects over Achilles region. Ten patients reported satisfactory results, while two patients had distal flap necrosis which was later covered with split thickness skin graft. Also, similar results were observed by Bullocks J.M. et al., [19] study in which 4 patients had Achilles tendon injuries and concomitant complex soft tissue defects. The reversed sural artery flap was planned in conjunction with the orthopedic surgeons to facilitate their approach for Achilles' tendon repair. Partial flap loss occurred in one patient and the Achilles repair was performed successfully in all patients.
The reversed sural artery flap is an excellent option for reconstruction of larger soft-tissue defects of the lower limb if the flap is delayed, as this has been shown to improve perfusion of the flap, resulting in an increased viability [20]. Dharmangaonkar and Patankar [21] used the reverse sural fasciocutaneous flap to resurface moderate to large soft tissue defects in the distal third of the leg and ankle in 109 patients. In contrast, our study included comparatively smaller wounds where muscle flaps can cover these wounds but at the expense of function [22].

Lateral supra malleolar artery flap was also performed in our study to cover raw area over Achilles' region in seven patients. The defects varied in size from small to medium size defects. Five cases showed satisfactory results and two patients had distal flap necrosis. Debridement and later coverage with split thickness skin graft was done in one case while, the other case was associated with a minimal flap loss which healed spontaneously by secondary intention. These findings are consistent with those reported by Hamdi MF [23] study. He used lateral supra malleolar flap to cover soft tissue defects of the ankle, heel, and foot. Seven cases showed satisfactory results and one case showed partial superficial necrosis which healed successfully by secondary intention.

In six patients, we used posterior tibial perforator artery flap to cover raw area in the Achilles region. The defects varied in size from small to medium size defects. Five cases showed satisfactory results. A case was associated with partial superficial necrosis which healed successfully through secondary intention. The posterior tibial perforator flap is also believed to have advantages. We preferred the aforementioned flap, due to its sufficiency for the of both the skin and the Achilles tendon region, with no need for microsurgical expertise. In addition, this flap could be used for minor or moderately sized defects. When the defect size is large, it is difficult for the pedicled perforator artery flap, or other regional flaps, to cover the entire wound. In the last decade, perforator flaps have become the workhorse for wound coverage. Compared with the traditional free latissimus dorsi free flap [24] and the free anterolateral thigh flap [11], they have the advantages of similar size, less thickness, and less donor site morbidity.43

In one patient, we used latissimus dorsi musculocutaneous free flap to cover raw area in the Achilles region. The defect was due to road traffic accident and the defect size was about $16 \times 12 \mathrm{~cm}$. Donor site was primarily closed and the case 
showed satisfactory results in terms of complete flap survival and coverage of the defect with no donor site morbidity and early restoration of function. Similar results were observed by Al Maksoud et al., [25] study, in which a case of a Marjolin ulcer on the heel in a 62-year-old woman resulted in a chronic non-healing wound. After excision of the tumor with safety margin, the Achilles tendon was exposed. The heel defect was reconstructed with a free latissimus dorsi musculocutaneous flap with delayed secondary closure. The outcome was successful both functionally and cosmetically. No further procedures were needed. In another study by Lee H-B et al., [24], free latissimus dorsi muscle flap was used in four cases for reconstruction of the overlying soft tissues. All free transplantations were successful with no complications.

There limitations in our study include the relatively small sample size and the heterogeneity among patient population and etiology. Additionally, we did not perform a comparison between the different types flaps and free flap. To our knowledge, no studies have directly compared these reconstructive procedures. Future well designed randomized controlled trials with larger sample sizes are needed to define an algorithm for the most appropriate flap reconstruction method based on the mode of trauma, site, and size of the defect.

\section{Conclusion:}

In summary, Achilles' tendon region has several injury mechanisms, which involve defects of the Achilles tendon, skin, and calcaneus. The reconstruction protocols should not be separated. Of the three structures, we emphasized that flaps are the best coverage option for defects in this area as they are good stable \& durable coverage. Lateral supra malleolar artery flap, perforator flaps and the distally based peroneus brevis muscle flap are best used for covering small to intermediate sized defects with good results. Reversed sural artery flap can be advocated for covering defects in the Achilles area, as it is successfully used for covering defects that varied in size from small to large defects. The use of free flaps is restricted mainly to complex and wide reconstructions, as it requires procedures and microvascular experience (Fig. 5).

\section{Acknowledgements:}

We are very grateful to experts for their appropriate and constructive suggestions to improve this template.

\section{Declarations:}

- Funding: No funding sources.

- Conflict of interest: Non declared.
- Ethical approval: This study was approved by the Institutional Review Board.

\section{References}

1- ASPLUND C.A. and BEST T.M.: Achilles tendon disorders. BMJ [Internet]. Mar 18; 346 (mar12 1): f1262f1262. Available from: https://www.bmj.com/lookup/doi/ 10.1136/bmj.f1262, 2013.

2- O'BRIEN M.: The Anatomy of the Achilles Tendon. Foot Ankle Clin [Internet]. Jun; 10 (2): 225-38. Available from: https://linkinghub.elsevier.com/retrieve/pii/ S1083751505000124, 2005 .

3- MARCHESI A., PARODI P., BRIOSCHI M., RICCIO M., PERROTTA R., COLOMBO M., et al.: Soft-tissue defects of the Achilles tendon region: Management and reconstructive ladder. Review of the literature. Injury [Internet]. Oct., 47: S147-53. Available from: https://. linkinghub.elsevier.com/retrieve/pii/S0020138316303618. 2016.

4- INNOCENTI M., INNOCENTI A., GHEZZI S. and DELCROIX L.: Achilles Region Soft-Tissue Defects: A Reconstructive Algorithm Based on a Series of 46 Cases. J. Reconstr. Microsurg. [Internet]. Oct 6; 33 (S 01): S40-7. Available from: http://www.thieme-connect.de/DOI/DOI? 10.1055/s-0037-1606554, 2017.

5- BAJANTRI B., BHARATHI R., RAMKUMAR S., LATHEEF L., DHANE S. and SABAPATHY S.R.: Experience with peroneus brevis muscle flaps for reconstruction of distal leg and ankle defects. Indian J. Plast. Surg. [Internet]. Jan 7; 46 (01): 048-54. Available from: http://www.thieme-connect.de/DOI/DOI? $10.4103 / 0970$ 0358.113706, 2013.

6- KNOBLOCH K., HEROLD C. and VOGT P.M.: Freier Latissimus-dorsi-Transfer zur Rekonstruktion von Weichteildefekten der unteren Extremität. Oper Orthop. Traumatol [Internet]. Apr 25; 24 (2): 122-30. Available from: http://link.springer.com/10.1007/s00064-011-0094-y, 2012.

7- CIOFU R.N., ZAMFIRESCU D.G., POPESCU S.A. and LASCAR I.: Reverse sural flap for ankle and heel soft tissues reconstruction. J. Med. Life [Internet]. 10 (1): 94 8. Available from: http://www.ncbi.nlm.nih.gov/ pubmed/28255387

8- NAMBI G.I. and VARANAMBIGAI T.K.A.: Clinical Study of the Lateral Supramalleolar Flap in the Soft Tissue Reconstruction around the Ankle Region. Indian J Plast Surg [Internet]. Mar 4; 53 (01): 083-9. Available from: http://www.thieme-connect.de/DOI/DOI?10.1055/s-00393402354, 2020.

9- SHEN L., LIU Y., ZHANG C., GUO Q., HUANG W., WONG K.K.L., et al.: Peroneal perforator pedicle propeller flap for lower leg soft tissue defect reconstruction: Clinical applications and treatment of venous congestion. J. Int. Med. Res. [Internet]. Jun 27;45 (3): 1074-89. Available from: http://journals.sagepub.com/doi/10.1177/ $0300060516687229,2017$.

10- IGNATIADIS I.A., GEORGAKOPOULOS G.D., TSIAMPA V.A., POLYZOIS V.D., ARAPOGLOU D.K. and PAPALOIS A.E.: Distal posterior tibial artery perforator flaps for the management of calcaneal and Achilles tendon injuries in diabetic and non-diabetic patients. Diabet Foot 
Ankle [Internet]. Jan. 12; 2 (1): 7483. Available from: https://www.tandfonline.com/doi/full/10.3402/ dfa.v2i0.7483, 2011.

11- HOUTMEYERS P., OPSOMER D., VAN LANDUYT K and MONSTREY S.: Reconstruction of the Achilles Tendon and Overlying Soft Tissue by Free Composite Anterolateral Thigh Flap with Vascularized Fascia Lata. J Reconstr Microsurg [Internet]. Mar 12; 28 (03): 20510. Available from: http://www.thieme-connect.de/ DOI/DOI?10.1055/s-0032-1306367, 2012.

12- CHANDRA V. and SINGH R.K.: Dorsalis Pedis Arterybased Flap to Cover Nonhealing Wounds Over the Tendo

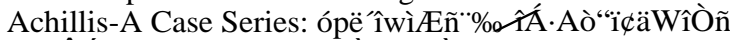
çáiIÊÓ\%FéËèpèùå -ånóÒïaó·iÒçê. J Orthop Trauma Rehabil [Internet], 22: 18-21. Available from: http://dx.doi.org/10.1016/ j.jotr.2015.12.004, 2017.

13- JIGA L.P., BARAC S., TARANU G., BLIDISEL A., DORNEAN V., NISTOR A., et al.: The Versatility of Propeller Flaps for Lower Limb Reconstruction in Patients With Peripheral Arterial Obstructive Disease. Ann Plast Surg [Internet]. Feb; 64 (2): 193-7. Available from: https://journals.lww.com/00000637-201002000-00020, 2010.

14- D'ARPA S., TOIA F., PIRRELLO R., MOSCHELLA F. and CORDOVA A.: Propeller Flaps: A Review of Indications, Technique, and Results. Biomed Res. Int. [Internet]. 2014: 1-7. Available from: http://www.hindawi.com/ journals/bmri/2014/986829/, 2014.

15- WEI Z-R., SUN G-F., WANG D-L. and TANG X-J.: Reconstruction of the Achilles Tendon and Overlying Skin Defect. Ann Plast Surg [Internet]. Sep., 73 (3): 3259. Available from: https://journals.lww.com/00000637201409000-00018, 2014.

16- ZHU Y.L., XU Y.Q., MEI L. BIN, WANG Y., LI F.B., SUN L.H.: Open Achilles tendon defects: A 12-year study on the injury mechanisms, reconstructions, and late complications. J. Reconstr. Microsurg., 30 (8): 569-80, 2014.

17- SAHU S., GOHIL A.J., PATIL S., LAMBA S., PAUL K. and GUPTA A.K.: Distally based peroneus brevis muscle flap: A single centre experience. Chinese J. Traumatol. [Internet]. Apr; 22 (2): 108-12. Available from: https://linkinghub.elsevier.com/retrieve/pii/S 1008127518 301627, 2019.

18- JACOB A.V.: University Journal of Surgery and Surgical Specialities. Univ. J. Surg. Surg. Spec., 5 (5): 1-5, 2019.
19-BULLOCKS J.M., HICKEY R.M., BASU C.B., HOLLIER L.H. and KIM J.Y.: Single-stage reconstruction of Achilles tendon injuries and distal lower extremity soft tissue defects with the reverse sural fasciocutaneous flap. J. Plast. Reconstr. Aesthetic Surg. [Internet]. May, 61 (5): 566-72. Available from: https://linkinghub.elsevier.com/ retrieve/pii/S 1748681506001434, 2008.

20- KNESER U., BACH A.D., POLYKANDRIOTIS E., KOPP J. and HORCH R.E.: Delayed Reverse Sural Flap for Staged Reconstruction of the Foot and Lower Leg. Plast. Reconstr. Surg. [Internet]. Dec., 116 (7): 1910-7. Available from: http://journals.lww.com/00006534-20051200000010, 2005.

21- TOUAM C., ROSTOUCHER P., BHATIA A., OBERLIN C. and TOUAM C.: Comparative Study of Two Series of Distally Based Fasciocutaneous Flaps for Coverage of the Lower One-Fourth of the Leg, the Ankle, and the Foot. Plast. Reconstr. Surg. [Internet], 107 (2). Available from: https://journals.lww.com/plasreconsurg/Fulltext/ 2001/02000/Comparative_Study_of_Two_Series_of_Di stally_Based.13.aspx, 2001.

22- TAYLOR G.I. and PAN W.R.: Angiosomes of the leg: Anatomic study and clinical implications. Plast Reconstr Surg [Internet]. Sep., 102 (3): 599-616; discussion 617 8. Available from: http://www.ncbi.nlm.nih.gov/ pubmed/9727424, 1998.

23- HAMDI M.F. and KHLIFI A.: Lateral Supramalleolar Flap for Coverage of Ankle and Foot Defects in Children. J Foot Ankle Surg [Internet]. Jan., 51 (1): 106-9. Available from: https://linkinghub.elsevier.com/retrieve/ pii/S 1067251611005795, 2012.

24- LEE H.B., LEW D.H., OH S.H., TARK K.C., KIM S.W., CHUNG Y.K., et al.: Simultaneous reconstruction of the Achilles tendon and soft-tissue defect using only a latissimus dorsi muscle free flap. Plast. Reconstr. Surg. [Internet]. Jul., 104 (1): 111-9. Available from: http:// . www.ncbi.nlm.nih.gov/pubmed/10597683, 1999.

25- AL MAKSOUD A.M., BARSOUM A.K. and MONEER M.: Squamous cell carcinoma of the heel with free latissimus dorsi myocutaneous flap reconstruction: Case report and technical note. J. Surg. Case Reports [Internet]. 2016 May 9; (5): rjw067. Available from: https://academic. . oup.com/jscr/article-lookup/doi/10.1093/iscr/riw067. 2016. 


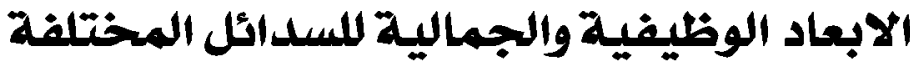

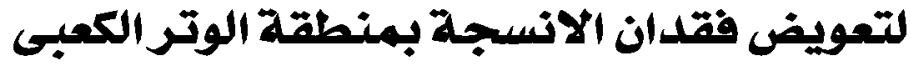

لاتخاذ القرار الصائب لتغطية وتر اخيل المكثوف لابد من معرفة ابعاد وعواقب العملية الجراحية ومدى استعادة المريض لطبيعته الصحية. لذلك يهدف هذا البحث إلى تقديم عرض للسدائل المتاحة لتفطية فقدان الانسجة في منطقة وتر اخيل وتحديد مدى كفائتهم. الغرض من البحث تحديد أفضل الملول الجراحية المتاحة لتغطية منطقة وتر اخيل المكثوف وتقييم العملية الجراحية من حيث النتائج الطبية والوظيفية والشكل الجمالى.

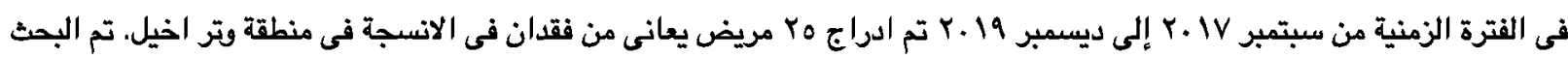

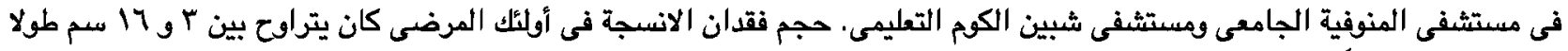

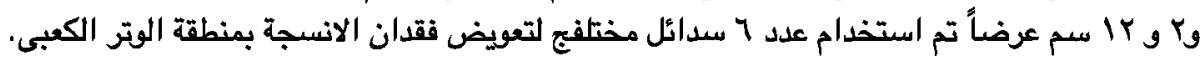

لم يكن هناك أى سديلة فقدت حيويتها بالكامل فى كل السديلات الجلدية المستخدمة ، تم استخدام السديلة الجلدية الجانبية فوق الكعبية

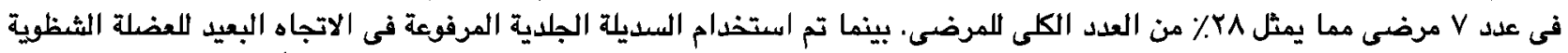

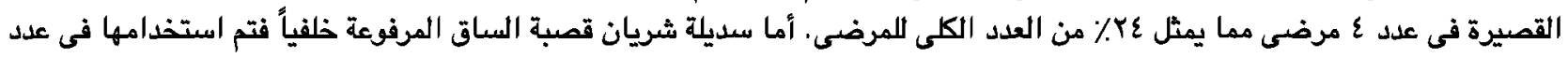

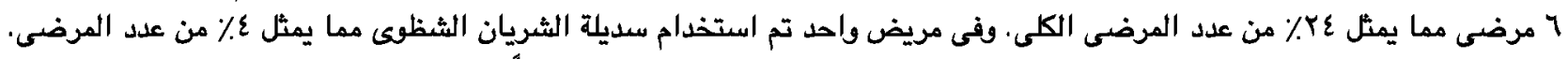

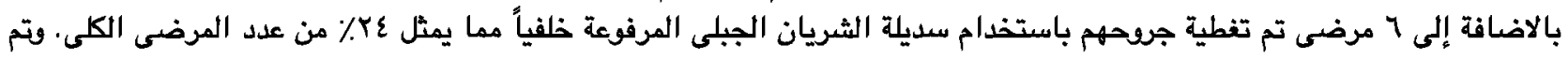

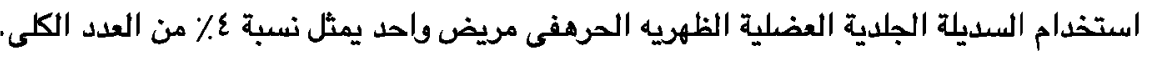

تم كحت وتظظف الجرح فى عدد r مرضى وتفطيته برقعه جلدية منقسمة السمك. هناك مريض واحد كان يعانى من قرحه جلدية مزهنة تم

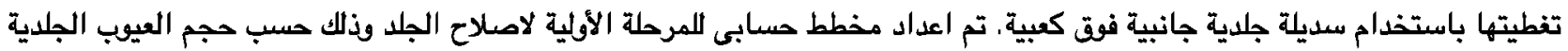
فى المرضى.

السديلات الجلدية الشريانية الثاقبة والسديلة الجلدية الخلفية فوق الكبية وكذلك السديلة الجلدية المرفوعة فى الاتجاه البعيد العضلة الشظوية

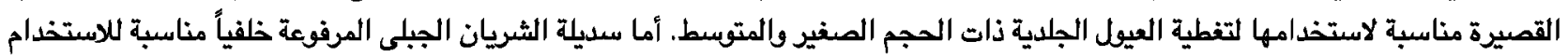
فى العيوب الجلدية ذات المجم المتوديط إلى الكبير. السديلات الحره هى الافضل تماماً لاصلاح العيوب الجلدية المعقدة الواسعة. 